\title{
Analysis and Forecast about China's Foreign Exchange Reserves Based on Grey System
}

\author{
Shiyun Yang \\ College of Economics and Management, Sichuan Agricultural University \\ Room 411, Unit 2, Building 6, Chengdu Campus of Sichuan Agricultural University \\ 211 HuiMin Road, District Wen Jiang, Chengdu 611130, China \\ E-mail: yangshiyun0023@hotmail.com \\ Dongmei Li (Corresponding author) \\ College of Economics and Management, Sichuan Agricultural University \\ 211 HuiMin Road, District Wen Jiang, Chengdu 611130, China \\ E-mail: cndldm@163.com \\ Received: September 14, $2011 \quad$ Accepted: November 9, $2011 \quad$ Published: February 1, 2012 \\ URL: http://dx.doi.org/10.5539/ass.v8n2p153
}

doi:10.5539/ass.v8n2p153

\begin{abstract}
Based on the Grey correlation analysis, the paper analyzes the influencing factors which affect the foreign exchange reserves in China. It also points out the main connected factors and forecasts the foreign exchange reserves in future by using $\operatorname{GM}(1,1)$ model.
\end{abstract}

Keywords: Foreign exchange reserves, Grey correlation analysis, Grey prediction

\section{Introduction}

Foreign exchange reserves refer to the foreign exchange of international reserve assets which held by a country's government, namely the creditor right in foreign currency retained by a country, that is the convertible foreign assets held by a country or region monetary authority. As an important part of a national economic strength, Foreign exchange reserve is the foreign exchange accumulation used by a government to balance international payments, stabilize exchange rate, and repay foreign debt. In contemporary economic society with deepening internationalization, Foreign exchange reserves play an increasingly important role in the steady development of one country.

At the beginning of the reform and opening, the size of China's foreign exchange reserves was very small, which even had appeared negative number in a few years. Since 1994 China has reformed in the foreign exchange system, and began to implement a "based on market supply and demand, a single, managed floating exchange rate system", under the promotion of double surplus in international balance in about continual ten years, the foreign exchange reserves increased substantially. In June 2009, China's foreign exchange reserves exceeded more than 2 trillion dollars, becoming the country which had the first largest foreign exchange reserves in the world.

\section{Related literature reviews}

The research about foreign exchange reserves started earlier in foreign countries, and prevailed in the 1960s and 1979s.Kenen Yudin (1965) considered several factors' influence on the size of foreign exchange reserves, the selection of the variable though lacking of empirical support but also hold in logic.Frenkel (1974) used cobb-douglas function to build optimization mathematical model of foreign exchange reserves, researched the relationship between the variables such as one country's Import-export, the fluctuation of International payment and the requirements of foreign exchange reserves. Lane and Burke (2001) put forward taking the share of foreign exchange reserves in GDP as explanatory variables to broaden the thinking way of foreign exchange reserves model. 
In recent years, the high growth of China's foreign exchange reserves with RMB exchange rate appreciation problem has made foreign exchange reserves become one of the core issues that the theory and academic circles of our country discuss and pay attention to. Liu Xuesong \& Cao Xianbing (2006) used the annual data from 1979 to 2005, adopting the Co integration Analysis method to research the moderation of foreign exchange reserves. Shi Huanping (2007) analyzed and judged the unbalance growth of China's foreign exchange reserves, discussed the causes and analyzed the potential influence on our country's economy development and macro-control. Wang Qi (2008) used China's 10 month's foreign exchange reserves in 2007 to derive a prediction model about the size of foreign exchange reserves by grey prediction method and on this basis predicted the future foreign exchange of the country. Tian Yunqing (2010) discussed the potential influencing factors on our foreign currency reserves from the aspects of supply and demand. Compared to foreign scholars' research, the empirical analysis about foreign exchange reserves in China's scholars is less, of which uses static mode for quantitative analysis, so the research system needs to be improved.

This paper selects the macro economic data in China to predict the foreign exchange reserves and analyses the influencing factors by grey system method. In order to grasp the growth trend of China's foreign exchange reserves, inform its growth internal cause and the assistant impetus, this paper would give some suggestions about standardizing national moderate foreign exchange reserves amount.

\section{Grey correlation analyses}

\subsection{The information for variables and data selection}

At present, Factor Analysis is widely used to determine the appropriate scale of foreign exchange reserves. Generally, the influencing factors of foreign exchange reserves include: The economic development level and opening degree, foreign trade condition and financial market development level, exchange rate system and policy, foreign investment and the status of a country's currency. On the basis of theory and practice research about foreign exchange reserves in foreign, combining with the actual situation of our economic development, through summarizing the influencing factors of foreign exchange reserves and taking practical data in consideration, this paper choose the following five representative variables and use the Grey Correlation to analyze.

GDP: real GDP reflects a country's economic size and the demand for foreign exchange reserves, the higher the proportion of foreign exchange reserves in GDP is, the greater the country's opening degree is.

Balance foreign debt: On one hand, Balance foreign debt constitutes the direct or indirect supply for a nation's foreign exchange reserves. On the other hand, repay principal and interest of the foreign debt constitutes direct demand for foreign exchange reserves. The bigger a country's balance foreign debt is, the more the balance of short-term foreign debts is, the more the need of repay principal and interest is. So, in order to maintain certain repay ability should hold more foreign exchange reserves. Choosing balance foreign debt as influences of foreign exchange reserves can comprehensively reflect the influence of foreign exchange reserves from supply and demand.

Foreign direct investment: foreign investment enterprises' remitted foreign profits constitute the important content of foreign exchange reserves needs, it can affect foreign exchange reserves from capital and financial project, also from current account through import-export .Taking the foreign direct investment as a factor is considering that foreign direct investment makes the supply of foreign exchange reserves, on the other hand also because the future remitted foreign profits amount will constitute the potential demand for foreign exchange reserves.

Import-export balance: from the source structure of foreign exchange reserves, a large part of annual reserves is made up of the accumulation difference of current account. A country's international payment equals to the difference of import and export, when export is more than import that is surplus. Otherwise deficit and the government must use the country's international reserves to pay for. So, the import-export difference can be used as an index to measure foreign exchange reserves.

Annual average exchange rate: one of the foreign exchange reserves' role is to stabilize exchange rate, so there is a close relationship between the reserve requirement system and the exchange rate. The change of an annual average exchange rate in a certain period reflects the national government exchange rate system, also further reflects foreign exchange reserves the Central Bank of a country use to keep some kind of exchange rate. Our country executes the floating exchange rate system under reasonable management. The exchange rate is not much sensitive to economy, but due to existence of the RMB appreciate expectation, small-scope fluctuation of exchange rate will still cause big changes of foreign exchange reserves level. So, we can choose annual average 
exchange rate as variables index to investigate the influence which exchange rate system make on foreign exchange reserves.

According to $<$ China statistical yearbook $>$, the database of national statistics bureau, we can get the data of China's foreign exchange reserves and influencing factors in 2005 -2010 years as Table 1.

\subsection{Establishment and analysis of model}

Suppose that actual foreign exchange reserves in China is $X 0$, so: Reference sequence $X_{0}=\left\{X_{0}(k), k=1,2, \ldots \ldots 6\right\}$; Comparison sequence $X_{i}=\left\{X_{i}(k), k=1,2, \ldots \ldots 6\right\}$, among them $k$ represents sample size, $i(i=1,2,3,4,5)$ refers to influencing factors.

1) Firstly, use initial value processing method to dimensionless deal with the data, Formula for:

$$
\mathrm{X}_{\mathrm{i}}=\frac{x_{i}(k)}{x_{i}(1)}
$$

2) Calculate the absolute difference value of each year between comparison sequence and reference sequence

$$
\Delta_{i}(k)=\left|x_{0}(k)-x_{i}(k)\right|
$$

According to the absolute difference, Calculate max difference $\max _{i} \max _{k}\left|x_{0}(k)-x_{i}(k)\right|=2.65$, and $\min$ difference $\min _{i} \min _{k}\left|x_{0}(k)-x_{i}(k)\right|=0.00$

Calculate the correlation coefficient of sequences $X_{0}(t)$ and $X_{i}(t)$ on time k, resolution coefficient $\xi=0.5$, and among them:

$$
\xi_{i}(k)=\frac{\min _{i} \min _{k}\left|x_{0}(k)-x_{i}(k)\right|+0.5 \max _{i} \max _{k}\left|x_{0}(k)-x_{i}(k)\right|}{\left|x_{0}(k)-x_{i}(k)\right|+0.5 \max _{i} \max _{k}\left|x_{0}(k)-x_{i}(k)\right|}
$$

3) Calculate grey correlation degree of the factors

$$
r_{i}=\frac{1}{N} \sum_{k=1}^{N} \xi_{i}(k)
$$

Get $r_{1}=0.729 ; r_{2}=0.686 ; r_{3}=0.673 ; r_{4}=0.687 ; r_{5}=0.595$, correlation sort $r_{1}>r_{4}>r_{2}>r_{3}>r_{5}$

According to the above conclusions, Grey correlation analysis showed that:

(1) GDP is the main factor which affect foreign exchange reserve requirement. In China the economic growth is related to opening degree, economic growth make GDP increase, and the foreign opening degree also increase gradually in turn, leading to the gradual increase of foreign exchange.

(2) Import-export balance is a major influencing factor of China's foreign exchange reserves needs. Due to the fact that we have a capital inflow and small amount of output, China's foreign exchange reserves are mainly from the total accumulative balance of import-export under the current account. The most basic role of foreign exchange reserve is to make up the payment deficit of international balance, so it needs to keep a certain relation with one country's foreign trade level. The correlation analysis shows that the larger the number of China's foreign trade is, the more foreign exchange reserves we need.

(3) Foreign direct investment has more influence on foreign exchange reserves. The utilization of foreign direct investment can relief funds shortage of our country in some degree and promote economic growth. But foreign direct investment have high returns, nearly $10 \%$ of the surplus profit convert into investor each year, this part of the funds should be paid with foreign exchange, which has a direct impact on China's foreign currency reserves, so we can conclude that foreign direct investment profit maintained a close contact with foreign exchange reserves steadily. In the past dozens of years, domestic policy supported the development of foreign investment, thus, there appeared a large scale of investment momentum, a large number of foreign direct investments played an important role to rapid the growth of China's foreign exchange reserves. Therefore, the foreign direct investment is a great factor that affects our country's largest foreign exchange reserves.

(4) Scores of External debt balance and foreign direct investment are nearly equal, External debt balance also has large effect on foreign exchange reserves. Raise foreign debt can promote a country's economic development to some extent, China take out some special fund from foreign exchange reserves as sinking fund, obviously, the bigger the external debt balance scale is, the closer the maturity is, the bigger the foreign exchange reserve used in debt service is. From Table 1, the external debt balance of our country is increasing year by year, foreign debt 
has become a powerful source of funds in China's economy .At the end of 2010, China's foreign debt balance was 548.938 billion dollars, long-term debt balance was 173.243 billion dollars, short-term foreign debt balance was 375.695 billion dollars, accounting for $68.44 \%$ of the debt balance, far higher than international alarming levels. From the above Grey correlation analysis, it is known that the national debt balance is one of the main reasons which affect our country's foreign exchange reserves, It is because of our country's high short-term foreign debt level as well as the maturity of the 1990s'external debt that we need to hold large foreign exchange reserves to pay for. Therefore, external debt balance can also be an important factor to determine appropriate scale of China's foreign exchange reserve.

(5) In opening economy, a country's exchange rate is based on market supply and demand, its influence on foreign exchange reserves should be great, We need a certain amount of foreign exchange reserves to guarantee the effect of the exchange rate of RMB on dollar is only based on market supply and demand since our country implemented the floating exchange rate system. So, the empirical analysis results show that the influence degree of average annual exchange rate effect on the scale of foreign exchange reserves are not as significant as expected.

\section{Trend forecast}

GM $(1,1)$ grey model as a kind of forecasting theory, has been full applied in academic circle. Certain foreign exchange reserves is the important means for a country to proceed economic regulation and get internal and external balance, so predicting the total state foreign exchange reserves has realistic significance.

According to the actual foreign exchange reserve balances (Unit: billion dollars) in 2005-2010 years, the original data is

$X^{0}(k)=(8188.72,10663.40,15282.49,19460.30,23991.52,28473.00)$, Establishing GM $(1,1)$ model and forecasting.

1) For the original data a accumulation generation to get

$$
X^{1}(k)=\left(\begin{array}{lllllll}
8188 & .72,18852 & .12,34134 & .61,53594 & .91,77586 & .43,106059 & .43
\end{array}\right)
$$

2) Using least square estimation to get parameters $\hat{a}=\left(B^{T} B\right)^{-1} B^{T} Y_{N}$ which,

$$
B=\left[\begin{array}{ll}
-\frac{1}{2}\left(x^{1}(1)+x^{1}(2)\right) & 1 \\
-\frac{1}{2}\left(x^{1}(2)+x^{1}(3)\right) & 1 \\
-\frac{1}{2}\left(x^{1}(3)+x^{1}(4)\right) & 1 \\
-\frac{1}{2}\left(x^{1}(4)+x^{1}(5)\right) & 1 \\
-\frac{1}{2}\left(x^{1}(5)+x^{1}(6)\right) & 1
\end{array}\right]=\left[\begin{array}{cc}
-13520.42 & 1 \\
-26493.365 & 1 \\
-43864.76 & 1 \\
-65590.67 & 1 \\
-91822.93 & 1
\end{array}\right]
$$

$Y_{N}=\left[x^{0}(2), x^{0}(3), x^{0}(4), x^{0}(5)\right]^{T}=(10663.40,15282.49,19460.30,23991.52,28473,00)$

and get:

$$
\hat{a}=(a, u)^{T}=\left(B^{T} \mathbf{B}\right)^{-1} B^{T} Y_{N}=(-0.223,8831.977)^{T}
$$

Get first order linear differential $\frac{d X^{1}}{d t}-0.223 X^{1}=8831.977$

Its time response sequence is $\hat{x}^{1}(k+1)=\left(x^{0}(1)-\frac{u}{a}\right) e^{-a k}+\frac{u}{a}=47865 \quad .765 e^{0.223 k}-39677 \quad .045$
3) Model test:

Residual test on the model with time response function to calculate $x^{1}(k)$, using function

$$
\hat{x}^{0}(k)=\hat{x}^{1}(k)-\hat{x}^{1}(k-1)
$$

To calculate reduction data, Get residual value $\mathrm{q}(\mathrm{k})$ and relative error e $(\mathrm{k})$ of each period. The calculation results see Table 2 as follow.

Calculate with the data in the Table 2 to get:

$$
\overline{X_{1}}=17676.57 \quad S_{1}=7124.59 \quad \overline{X_{2}}=10.11 \quad S_{2}=744.70 \quad C=\mathrm{S}_{2} / \mathrm{S}_{1}=0.1045
$$


From that, the average error of the model is no more than $5 \%, \mathrm{P}=6 / 6=1>0.95, \mathrm{C}=0.1045$, model effect is better, can be used to predict.

4) Using model to predict:

When $\mathrm{K}=6$, obtain by model: $\hat{x}^{1}(7)=47865 \quad .765 e^{0.223 * 6}-39677 \quad .045=142318 \quad .1773$

$$
\hat{x}^{0}(7)=\hat{x}^{1}(7)-\hat{x}^{1}(6)=36319.40
$$

It is predicted that China's foreign exchange reserve balance will be 3.63194 trillion dollars in 2011, and in turn we can get $\$ 4.537442$ trillion, $\$ 5.668702$ trillion, $\$ 7.082003$ trillion, $\$ 8.847664$ trillion from 2012 to 2015.According to this, in the next few years China's foreign exchange reserves will rise year by year. High foreign exchange reserves have enhanced our comprehensive national strength, international pay ability and ability to cope with external economic impact and financial crisis, and have improved the confidence of international community to our country about the currency and economic stability, and have expanded the influence of our country in international economic activities. But on the other hand, the higher reserves will bring some negative effects. A large number of foreign exchange will seriously reduce the effectiveness of the Central Bank monetary policy, the high foreign exchange reserves may cause opportunity cost and devaluing risk, which may affect the economy long-term stability and healthy development.

\section{Conclusion and suggestion}

This paper firstly analyzed China's foreign exchange reserves and the influence factors in grey correlation by using grey system based on actual data. The results show that GDP is the main factor influencing on the scale of China's foreign exchange reserve. Import-export balance, foreign direct investment, foreign debt balance and Annual average exchange rate also have important effect on our country's foreign currency reserves, and there is no big difference among the factors on moderate scale. they all directly affect the change of China's foreign exchange reserves. In the growing economic globalization today, as a symbol of a country's economic strength and foreign credit level, the foreign exchange reserves is playing a more and more important role .After analyzing the influencing factors of China's foreign exchange reserves scale, we should embark from these factors, and strengthen the management of China's foreign exchange reserve to improve its efficiency. China's foreign exchange reserves cost is high, if huge foreign exchange reserves cannot effectively turn into investment and consumption it will cause a negative effect on economic growth. Therefore, the government should judge the situation to keep a proper China's foreign exchange reserves, make foreign currency reserves play out the optimal utility in promoting economic development and improving our national status.

In addition, through establishing GM $(1,1)$ model to forecast the future China's foreign exchange reserve balances, the result shows that China's foreign exchange reserves still maintained strong growth in future years. As the biggest foreign exchange reserves country, our huge foreign exchange reserves have caused wide attention at home and abroad. In foreign country, China's large foreign exchange reserves become the main reason for high developed countries such as the United States to ask for RMB exchange rate appreciation, which makes the RMB faced greater appreciation pressure. In China, the scholars begin to focus on whether the foreign exchange reserves are exorbitant and how to maintain it in a moderate scale. The mutual interaction of foreign currency supply and demand decides the size of foreign exchange, so to maintain a moderate scale needs take both of them into account. It is predicted that China's foreign exchange reserves scale will continue to increase in the short term. On one hand, the sustained development of foreign exchange reserves in our country provides protection for the economic development and financial security, which are benefit to strengthen our country's international credit line; On the other hand, it will lead to decreasing efficiency of capital utility, economic structure imbalance problem and so on. In China's current economic development level, controlling the scale of foreign exchange reserves is not the most important thing, while how to manage foreign exchange reserves well, improve its operation efficiency to reduce the negative impact on macroeconomic is the key. This requires the government and state to combine the existing theory with the actual situation in our country, from four aspects of --- strengthening adjustment of import and export industrial structure, deepening the reform of the foreign exchange system, controlling short-term foreign debt growth, innovating foreign exchange reserves management to make reasonable planning and management on foreign exchange reserves, to develop economy and increase national strength and improve people's standard of living.

\section{References}

Chen Xiangguang \& Liu ying. (2008). The growth factors of China's foreign reserves and empirical test. Journal of Beijing Administrative College, (6). 
Guo Haijun \& Cai Yuezhou. (2006). The empirical analysis about China's foreign exchange reserves. Economic Review, (02).

Li Bei. (2005). The empirical analysis about influencing factors of foreign exchange reserves scale. Commercial Times.

Liu Chuanzhe. (2007). An empirical analysis about influencing factors and forecast about the scale trend of China's foreign exchange reserves. Finance and Economy, (11).

Liu Rui. (2010). The management measures and suggestions about strengthening our country foreign exchange reserves. Market Modernization, (9).

Pan Lifang. (2008). Analysis about influencing factors of China's foreign exchange reserves-based on the data of 1986-2006 yesrs. Economic\&Trade Update, (1).

Tian Yunqing. (2010). Analysis about influencing factors of our foreign exchange reserves. Market Modernization, (11).

Wang Qi. (2008). Forecast about total state of foreign exchange reserves based on the grey system theory. Market Modernization, (9).

Xing Dawei. (2006). An empirical study about the influencing factors of foreign exchange reserves moderate scale. Business Studies, (20).

Yuan xi \& Yuan Jianxin. (2011).The analysis and countermeasures about China's foreign exchange reserves status. China Market, (1).

Zhang Peng \& Xiang Jiamin. (2006). Analysis about the trend and influencing factors of China's foreign exchange reserves. Journal of Chongqing University, (11).

Table 1. Five indicators and actual foreign exchange reserves data table in $2005-2010$

\begin{tabular}{|c|c|c|c|c|c|c|}
\hline Year & $\begin{array}{c}\text { Foreign exchange } \\
\text { reserves } \\
\mathrm{X}_{0} \\
\text { (trillion dollars) }\end{array}$ & $\begin{array}{c}\mathrm{GDP} \\
\mathrm{X}_{1} \\
\text { (trillion) }\end{array}$ & $\begin{array}{c}\text { Balance } \\
\text { foreign debt } \\
\mathrm{X}_{2} \\
\text { (trillion) }\end{array}$ & $\begin{array}{c}\text { Foreign direct } \\
\text { investment } \\
\mathrm{X}_{3} \\
\text { (trillion) }\end{array}$ & $\begin{array}{c}\text { Import-export } \\
\text { balance } \\
\mathrm{X}_{4} \\
\text { (trillion) }\end{array}$ & $\begin{array}{c}\text { Exchange rate } \\
\mathrm{X}_{5} \\
\text { (Yuan) }\end{array}$ \\
\hline 2005 & 0.818872 & 18.493737 & 0.281045 & 0.060325 & 0.102000 & 819.17 \\
\hline 2006 & 1.066340 & 21.631443 & 0.322988 & 0.063021 & 0.177480 & 797.18 \\
\hline 2007 & 1.528249 & 26.581030 & 0.373618 & 0.074768 & 0.261825 & 760.40 \\
\hline 2008 & 1.946030 & 31.404540 & 0.374661 & 0.092395 & 0.298131 & 694.51 \\
\hline 2010 & 2.399152 & 34.050690 & 0.428647 & 0.090033 & 0.195689 & 683.10 \\
\hline
\end{tabular}

Data sources: $<$ China Statistical Yearbook $>$, the database of national statistics bureau

Table 2. The residual test of grey predict

\begin{tabular}{|c|c|c|c|c|c|c|}
\hline $\mathrm{K}$ & $\hat{x}^{1}(k)$ & $\hat{x}(k)$ & $x^{0}(k)$ & $\mathrm{q}(\mathrm{k})$ & $\mathrm{e}(\mathrm{k}) \%$ & $\mid q^{0}(k)-\overline{q^{0}}$ \\
\hline $1(2005)$ & 8188.72 & 8188.72 & 8188.72 & 0.00 & $0.00 \%$ & 10.11 \\
\hline $2(2006)$ & 20122.45 & 11933.73 & 10663.40 & -1270.33 & $-11.91 \%$ & 1280.44 \\
\hline $3(2007)$ & 35031.45 & 14909.00 & 15282.49 & 373.49 & $2.44 \%$ & 363.38 \\
\hline $4(2008)$ & 53657.52 & 18626.07 & 19460.30 & 834.23 & $4.29 \%$ & 824.13 \\
\hline $5(2009)$ & 76927.37 & 23269.85 & 23991.52 & 721.67 & $3.01 \%$ & 711.56 \\
\hline $6(2010)$ & 105998.78 & 29071.41 & 28473.00 & -598.41 & $-2.10 \%$ & 608.52 \\
\hline
\end{tabular}

